\title{
Thinking Copenhagen: the cognitive dimension of climate change policy making in Brazil and the United States
}

Mark S. Langevin ${ }^{1}$

\begin{abstract}
This article explores the cognitive dimension of climate change policy making in Brazil and the United States as both countries prepare for the Conference of the Parties to the United Nations Framework Convention on Climate Change or COP15 in Copenhagen. The comparative policy analysis is framed by Putnam (1988) and informed by Bazerman (2009), but adapted to explore the cognitive expressions of policymaking through investigation of public opinion, newspaper coverage, and policymaker statements. The analysis reveals key differences in the ways that Brazilian and U.S. citizens, journalists, and policymakers understand global warming and climate change and think through the policy alternatives for addressing this global challenge through national policy and international negotiations. Brazil's cognitive dimension provides its negotiators with a wide range of strategic positions, allowing this country to play the role of dealmaker. The U.S. administration arrives at Copenhagen with a narrow win-set, limited by the discordant and divisive cognitive expressions that surround policymaking. These differences limit bilateral cooperation and complicate the COP15 negotiations.
\end{abstract}

Keywords: Climate change. Cognitive dimension and expressions. Global warming. Greenhouse gas emissions. International treaty negotiations. Kyoto Protocol. Newspaper and media coverage. Policymaking. Public opinion. United Nations Framework Convention on Climate Change.

\footnotetext{
${ }^{1}$ Director BrazilWorks, Adjunct Associate Professor Department of Government and Politics University of Maryland-University College, Associate Researcher Laboratório de Estudos Politícos (LEP) Universidade Federal de Espirito Santo (UFES). E-mail: Mark.brazilworks@gmail.com.
} 


\section{Introduction}

Brazil and the United States are poised to play key roles at the Conference of the Parties to the United Nations Framework Convention on Climate Change or COP15 in Copenhagen and the negotiations over a post-Kyoto Protocol regime to reduce greenhouse gas (GHG) emissions. The COP15 promises to focus the world's attention upon the global challenge to move toward a low carbon energy economy. Next to U.S. -China energy and climate change policy cooperation (LIEBERTHAL; SANDALOW, 2009; PEW RESEARCH CENTER, 2009a) there may be no more important a bilateral relation in determining the outcome of the COP15 negotiations and the future of international climate change cooperation than that of Brazil and the United States.

Bilateral cooperation between these two nation-states was instrumental to reaching the agreement to establish the innovative Clean Development Mechanism (CDM) during the negotiations leading up to the Kyoto Protocol of the United Nations Framework Convention on Climate Change (UNFCC) in 1997 (OBERTHÜR; OTT, 1999, p. 167; VIOLA; LEIS, 2001). A decade later former U.S. President George W. Bush and current Brazilian President Luis Inácio Lula da Silva signed the Memorandum of Understanding Between the United States and Brazil to Advance Cooperation on Biofuels to foster investment in the production of low carbon, renewable transportation fuel production, namely ethanol and biodiesel, and lessen GHG emissions while sidestepping the ongoing commercial conflict over the U.S. tariff on Brazilian ethanol (LANGEVIN, 2008). In March of 2009, recently elected U.S. President Barack Obama welcomed President Lula to the White House to call attention to his proposed Energy Partnership for the Americas, highlight the importance of U.S.Brazil bilateral relations, and underscore each government's commitment to deepen cooperation on "clean energy" to confront the perils of global warming.

While much attention has been paid to U.S.-Brazil relations and the bio-fuel question (see LANGEVIN; BAEZA, 2009 for a review), few have fully examined the potential arc of bilateral cooperation on energy and greenhouse gas (GHG) emission reductions as the world prepares for the COP15 negotiations. ${ }^{2}$ Accordingly, The

\footnotetext{
${ }^{2}$ For an overall review of U.S.-Brazil relations see SEELKE; MEYER, 2009. For a regional perspective on energy cooperation see WEINTRAUB; PRADO; HESTER, 2007.
} 
Inter-American Dialogue (2009, p. 18) finds the bilateral relationship deficient in these policy areas and suggests,

The potential for productive collaboration may be even greater in the areas of climate change, environmental protection, and energy sources. Brazil is widely regarded as an important international actor in each area, and has committed itself to actively engaging all of them. Moreover, since Obama became president, these issues have become prominent on Washington's global agenda-substantially expanding the opportunities for U.S. cooperation with Brazil and other countries.

Carlos A. Cavalcanti, Vice President of Brazil's Supreme Council on Foreign Commerce (COSCEX) and Diego Z. Bonomo of the Brazil Industries Coalition (BIC) also point to the possibility of expanding bilateral cooperation on energy and climate change,

The U.S. is coming back to the negotiating table to construct a new international regime to address climate change. This new initiative is combined with a significant effort to de-carbonize its economy, change its energy matrix, and adapt its industrial base. For Brazil, it is of great interest to accompany these changes and prepare itself for the opportunities that arise through bilateral, regional, and multilateral initiatives, with an emphasis on energy (CAVALCANTI; BONOMO, 2009, p. 1). ${ }^{3}$

Under the tent of Copenhagen, there may be no better moment for accelerating bilateral cooperation to reduce GHG emissions. The Obama administration has already set in motion measures to place "green" energy policies and programs as the cornerstone to a new era of economic development (HOUSER; MOHAN; HEILMAYR, 2009) and Brazil continues to march toward the centerstage of international energy and climate change politics (ISBELL, 2008; SENNES; NARCISO, 2009). Yet, there are important differences between these pivotal countries that complicate bilateral cooperation and undermine efforts to achieve international consensus on a post-Kyoto Protocol regime for reducing GHGs and ushering in a new era of sustainable development based on renewable and low carbon energy. How do the citizens and elected leaders of these two nations think differently about global warming and the challenge of reducing GHGs? Do they

\footnotetext{
${ }^{3}$ All quotations from Portuguese language sources were translated by the author.
} 
share sufficient cognitive understanding of the challenges and possible solutions to expand bilateral cooperation and play a decisive, shared role in galvanizing an international agreement to address global warming?

This article does not propose that the cognitive dimension of policymaking determines climate change policy. Rather, variation in the ways that citizens and policymakers understand problems and develop solutions stem from the distributional conflicts over the costs and benefits of domestic policies and the national obligations arising from international treaty negotiations. Cognitive expressions; the observable comments and perspectives offered by citizens, journalists, and policymakers to explain, advocate or justify particular policy preferences and strategic positions for international treaty negotiations; offer an accessible and comparative range of observations for study. Such expressions compose a country's cognitive dimension of policymaking, one of many arenas through which the distributional conflict is waged, and eventually won by a coalition of factional interests. Thus, this examination of the cognitive dimension of climate change policy making in Brazil and the United States serves to expose several, but not all of the key differences between these two countries, differences that can be effectively observed and analyzed thereby contributing to a broader understanding of climate change policymaking and the possibilities for cooperation between these two pivotal players in the global efforts to meet the challenge of global warming.

This comparative policymaking study is framed by Putnam's (1988) international negotiation and ratification theory and partly informed by Bazerman's (2009) "barriers to acting in time." Putnam proposes that national governments, such as Brazil and the U.S., hold distinct "win-sets" for international treaty negotiations, such as those of the COP15 to extend the Kyoto Protocol beyond 2012. Each national government's win-set is composed of strategic positions that reflect a national distribution of costs and benefits among particular private or "factional" interests and that the winning coalition of beneficiaries can deliver domestic ratification. For Putnam, international negotiations include bargaining between national negotiators, called Level I, and bargaining among domestic factional interests which determine the win-set and possibilities of ratification; this is referred to as Level II. Putnam's framework steers investigation toward a deeper understanding of the bargaining dynamic between two or more nation-states 
by seeking explanation of a given national government's win-set and prospects for ratification at Level II. Accordingly, successful Level I negotiations between government negotiators identifies points of "overlap" between national win-sets and thereby frame international agreements which can be ratified at home without defection. Although Putnam argues that when national governments hold broad "win-sets" the probability of reaching agreement at Level I increases in proportion to the overlapping strategic positions held by the negotiators, he also notes that government negotiators who appear to hold large win-sets may get "pushed around" due to their capacity to make greater concessions to reach agreement. In this respect, the cognitive expressions of citizens and policymakers in Brazil and the U.S. contribute toward the formation of national strategic positions and winsets, as well as frame international perceptions about the size and flexibility of each country's respective win-set.

Putnam's analytical framework incorporates both the domestic politics underlying international treaty negotiations and their impact on the give and take in bargaining between national government negotiators. In most cases, Putnam's theory of international agreement and ratification provides for compelling explanation of the range of conflict and cooperation over international commercial and macro-economic negotiations (for an example see LANGEVIN, 2006). Bazerman (2009) also recognizes the importance of domestic politics in framing the outcome of international environmental treaty negotiations such as the COP15. In his examination of U.S. energy and climate change policymaking, Bazerman (2009, p. 64) asks, "Why don't wise leaders follow through when the expected benefits of action far outweigh the expected costs from a long-term perspective." He argues that effective legislation to move toward a low carbon energy economy must overcome "cognitive barriers" among other obstacles to change.

Bazerman's notion of cognitive barriers, including the propensity to discount the future, reliance on positive illusions, and self-serving egoism among both citizens and policymakers, are as compelling as they are underspecified. Cognitive understandings of such complex and interlocking problems as global warming and climate change certainly shape citizens' preferences under representative democracy and no doubt hinder or encourage effective policymaking. However, Bazerman's conceptualization of cognitive barriers are underspecified to serve 
empirical inquiry of the distributional conflicts surrounding energy and climate change policymaking and international negotiations. Hence, this examination adapts Bazerman's conceptual-analytical framework by proposing that variation in the cognitive expressions of citizens and policymakers can partially reveal the key differences between Brazil and the U.S., both in terms of national policymaking and the limits to domestic ratification of a post-Kyoto Protocol regime agreement. For the purposes of this analysis, the variable cognitive expression is operationalized through publically accessible, representative observations of public opinion, newspaper coverage and editorials, executive branch leaders responsible for domestic and international climate change policy, and key legislators that play instrumental roles in domestic ratification. Such a modification to Bazerman's conceptual work contributes to an understanding of the cognitive dimension of policymaking by partially framing an analysis of the strategic positions, win-sets, and limits to domestic ratification of a post-Kyoto Protocol regime to reduce GHG emissions and respond to global climate change. Notwithstanding, a comprehensive examination would also require a focus on the structural, institutional, and political sources of climate change policymaking.

The first section examines public opinion in Brazil and the U.S. with respect to the environment, global warming, and efforts to address climate change. The second section explores newspaper coverage and editorials as cognitive expressions that reflect and shape public opinion, contour the policy debate, and interact with the distributional conflicts over the costs and benefits of particular policy preferences and strategic positions. The third section reviews statements made by policymakers, including executive branch officials and key legislative leaders responsible for developing national energy climate change policy, that serve to crystallize and frame the cognitive dimension of policymaking as well as limit the range of viable policy alternatives.

\section{Public opinion}

Public opinion can play a role in shaping the outcome of international negotiations over global warming and climate change, especially as it interacts with scientific knowledge (AÍMOLA; DIAS, 2007). Hence, the variation in cognitive 
dimensions expressed by Brazil and the U.S. may challenge negotiators at Copenhagen. Brazil's public opinion reflects a growing consensus among citizens and policymakers about the danger of global warming, the importance of the United Nations Framework Convention on Climate Change (UNFCC) in addressing the problem, and their country's unique leadership role within the developing world. Brazil's cognitive dimension of policymaking parallels the country's pursuit of economic development, but increasingly within a sustainable framework. U.S. climate change and energy policymaking is challenged by a much wider spectrum of cognitive expressions, largely fragmented by ideological and partisan divisions. This important difference is crystallized through the observed variation in public opinion between Brazil and the U.S., disclosing the formidable obstacles to achieving bilateral cooperation based on common concern.

Citizens of Brazil and the U.S. think very differently about the environment, global warming, and the need to lessen GHG emissions. According to the Pew Center's Global Attitude Surveys, during the last decade Brazilians have demonstrated an increasing interest in environmental protection. From 2002 to 2007, the number of Brazilian respondents expressing concern for environmental problems grew from twenty, 20 , to forty-nine, 49 , percent. U.S. respondents expressing the same level of concern grew from twenty three, 23 , to thirty seven, 37 , percent during the same period. While both countries demonstrated increasing worry over the environment, Brazil's rising preoccupation with environmental degradation was the largest of the Pew Center's forty seven nation-state sample during the period under study. The U.S. level of concern was considerably lower than those held by Brazilians, and much lower than the sample's European countries with comparable levels of economic development including: France, Italy, Sweden, and Spain, as well as South Korea and Japan in Asia.

The 2009 Pew Center Global Attitudes Project's survey (PEW RESEARCH CENTER, 2009b) follows up with this public opinion based investigation of national variation in concern over global warming and its consequences. Table one reports response rates to the Pew Center's question about concern for global warming. This table reports the proportion of respondents who either answered that global warming is a serious problem or not a problem at for Brazil and the U.S., as well as China (who had the lowest level of concern). Brazil led the sample with 
ninety, 90, percent stating that global warming is a serious problem; while only forty four, 44, percent of the U.S. respondents held such a belief. Interestingly, while Brazil's concern with global warming and the environment has grown in remarkable fashion since 2002; U.S. worry over this global problem actually decreased three percent since 2007 and ranked among the lowest levels of concern in the Pew Center's twenty five country sample (PEW RESEARCH CENTER, 2009b).

Table One: Is global warming a very serious problem?

\begin{tabular}{|c|c|c|}
\hline Nation-State & Very Serious & Not a Problem \\
\hline $\begin{array}{c}\text { Lowest in Sample } \\
\text { (China) }\end{array}$ & $30 \%$ & $1 \%$ \\
\hline U.S.A & $44 \%$ & $11 \%$ \\
\hline Brazil & $90 \%$ & $1 \%$ \\
\hline $\begin{array}{c}\text { Highest in Sample } \\
\text { (Brazil) }\end{array}$ & $90 \%$ & $1 \%$ \\
\hline
\end{tabular}

Source: (PEW RESEARCH CENTER, 2009b). Respondents were asked to respond to one of following three answers: Very serious, Somewhat serious, Not too serious, or Not a problem.

A second question asked in the Pew Center's survey asked respondents whether they agreed or disagreed with the following statement: People should be willing to pay higher prices in order to address global climate change.

Table Two: People should be willing to pay higher prices in order to address global climate change

\begin{tabular}{|c|c|c|}
\hline \multicolumn{2}{|c|}{ Nation-State } & Agree \\
\hline $\begin{array}{c}\text { Lowest in the Sample } \\
\text { (Jordan) }\end{array}$ & $15 \%$ & $73 \%$ \\
\hline U.S.A. & $41 \%$ & $55 \%$ \\
\hline Brazil & $44 \%$ & $41 \%$ \\
\hline $\begin{array}{c}\text { Highest in the Sample } \\
\text { (China) }\end{array}$ & $88 \%$ & $8 \%$ \\
\hline
\end{tabular}

Source: (PEW RESEARCH CENTER, 2009). Table Two does not report refused or did not answer. 
Here the Brazilian and U.S. responses converge, although Brazilians report higher levels of willingness to pay the costs of reducing GHG emissions at forty eight, 48, percent to the U.S. level of forty one, 41 , percent. Both the Brazilian and U.S. "agree" response levels converge around the median (47.84\%) for the sample, with China (88\%) and India (85\%) reporting the highest levels and Egypt (18\%) and Jordan (15\%) responding with the low points in the sample's range. In addition to these results, The Pew Center reports that Brazilians expressed a much higher level of agreement with the statement, "Protecting the environment should be given priority, even if it causes slower economic growth and some loss of jobs," at seventy nine percent as compared to the U.S. rate of sixty four percent (PEW RESEARCH CENTER, 2009b, p. 88). Given the disparities in overall development it is surprising that Brazilians are more willing that U.S. citizens to make sacrifices to protect the environment and address global warming.

The Pew Center's Global Attitudes Project surveys (2002, 2007, 2008, 2009b) reveal significant variation in public opinion on the environment and global warming between Brazilian and U.S. citizens. This essential difference in cognitive expression is doubled sided. Since 2002 Brazilians have expressed a growing concern for the environment and climate change that has developed into a strong national consensus that global warming is one of the world's most important challenges. In stark contrast, U.S. public opinion reveals only moderate concern over the environment and a relatively low level of agreement that global warming is a serious problem. U.S. citizens' preoccupation with global warming trails most of those nations with similar levels of economic development, and more importantly, has increasingly become a divisive issue in elections and partisan wrangling (BRYNER, 2008). In the Pew Center's polling of U.S. citizens between March 9-12, 2009, fifty nine, 59, percent of respondents favored limiting carbon dioxide emissions to address global warming. However, only forty two, 42, percent of self-identified Republicans favored such reductions while seventy, 70, percent of Democrats and sixty, 60, percent of independents support efforts to reduce these GHG emissions (PEW RESEARCH CENTER, 2009c).

Underlying this partisan divide in policy preferences is a wide gap in recognizing the scientific validity of global warming measures and concurrent models of climate change. Republicans express great doubt about the merits of the science 
and skepticism about the anthropogenic origins of climate change. According to the Pew Center, in January of 2007 sixty two, 62, percent of Republicans, eighty six, 86, percent of Democrats, and seventy eight, 78, percent of independents reported that the earth is warming (PEW RESEARCH CENTER, 2008). Less than two years later the Pew Center's polling found that the number of Republicans who believed in global warming had dropped by thirteen, 13, percent to forty nine, 49 , percent of the sample. Indeed, even the numbers for Democrats and independents fell by two and three percent respectively during this short period (PEW RESEARCH CENTER, 2008). The Pew Center polling not only reveals a partisan divide on the issue of climate change in the U.S., but adds evidence to the suggestion that such political division may be partially responsible for the recent reversal of the slow, but growing national trend toward greater concern for global warming. A 2009 Gallup poll reported that sixty six, 66, percent of Republicans thought that news of global warming was exaggerated, while only forty four, 44, percent of independents and twenty two, 22, percent of Democrats agreed (SAAD, 2009). While Brazilians by and large respect the science of climate change and understand the cautionary conclusions of the United Nation's Inter-governmental Panel on Climate Change (IPCC) (UNITED NATIONS, 2007), the U.S. population is bitterly divided over the merits of the research. Ironically, the efforts of former U.S. Vice-President Al Gore, which led to his sharing of the Nobel Peace Prize with the IPCC, may have contributed to the formation of Brazil's strong national consensus on the dangers of global warming, but has not increased the relative proportion of U.S. citizens concerned with this global challenge.

\section{Newspaper Coverage}

A number of studies document how newspaper coverage can shape public opinion and set the policymaking agenda (PALFREMAN, 2006), several feature a particular focus on the environment and global warming (ANTILLA, 2005; BOYKOFF; BOYKOFF, 2004; DIRIKX; GELDERS 2008; GONÇALVES, 2008; KUHA, 2009). Boykoff and Boykoff (2008, p. 127) attempt to "unpack the journalistic norm of balance, excavating this norm to see if its application is problematic when discussing the human contribution to global warming and resulting calls for action" 
More to the point of understanding how newspaper coverage, as a cognitive expression, bridges public opinion and policy making, Dirikx and Gelders (2008, p. 99) argue

Most people do not have any experience of global warming, so the media can play an important role. Even if a person is confronted with circumstances of extreme heat, floods or drought, he or she will still often depend on the news to link those events to global climate change... Thus, the media help to generalize personal experiences and translate science into popular discourse.

Variation in national and regional newspaper coverage, including editorial perspectives, are important forms of cognitive expression that can be compared both historically and cross-nationally as these studies demonstrate. This section offers a brief and limited synthesis of prominent studies of newspaper coverage of global warming and climate change in Brazil and the U.S. in order to reveal the variation in this form of cognitive expression. The analysis is extended by highlighting the wide range of editorial perspectives found in the U.S. and largely absent from the mainstream press in Brazil.

The measurable variation in public opinion on the environment and global warming found between Brazil and the U.S. is also reflected in newspaper coverage, but without the quantitative precision or statistical significance. However, a careful textual analysis does identify important differences in newspaper coverage and editorial perspective between Brazil and the U.S. as well as within the U.S. In Brazil, the Agência de Notícias dos Direitos da Infância (ANDI) studied the treatment of the climate change theme across a sample of fifty national and regional newspapers from 2005 to 2008 . ANDI documented an observable increase in the number of articles, commentaries, and editorials published on global warming during the period. During the first sixth months of 2007, ANDI (2009, p. 26-27). measured a nearly two hundred, 200, percent increase in the number of articles and other materials published by the sample. ANDI notes that this remarkable increase in editorial attention immediately followed the publication of the Stern Review (STERN, 2007), the widespread showing of Al Gore's documentary, An Inconvenient Truth, in Brazil, and issuance of a United Nations IPCC fourth assessment report (UNITED NATIONS, 2007) providing further scientific evidence of global warming (ANDI, 2009, p. 19). 
ANDI's detailed analysis also documents the propensity to report on "global warming," rather than other aspects of the climate change problematic and notes that in eighty percent, $80 \%$, of the sampled publications the scientific confirmation of the green house gas effect was taken for granted (2009, p. 29). Consequently, ANDI reports that only 9.5 percent of the sampled texts offered divergent perspectives on the topic, with 44.2 percent focused on mitigation strategies and 28.4 percent detailing the scope of climate change (2009, p. 31). In reviewing ANDI's findings and the existing research literature treating the Brazilian media, Gonçalves $(2008$, p. 11) concludes that

These coverage patterns demonstrate the media's growing preoccupation in amplifying its daily agenda on climate change issues [...] mostly from a pedagogical, didactic framework in order to make this complex policy issue more accessible to the majority of the population.

ANDI's findings contribute to a better understanding of the rapid shift in public opinion observed by the Pew Center's Global Attitudes Survey and the consolidation of a strong consensus supporting climate change action among Brazilians. Taken together, the sheer increase in reporting, the tendency to confirm the scientific findings on global warming, and the near absence of divergent opinions on the anthropogenic sources of GHG emissions in the pages of Brazilian newspapers serve to cultivate consensus and set a cognitive foundation among Brazilians that promotes high levels of concern and political support for vigorous mitigation policies.

U.S. news coverage is remarkably different than the Brazilian case. Several studies and investigative reports confirm that while coverage has expanded in recent years it has presented a mixed view on the science of global warming, questioned the anthropogenic sources, and highlighted and associated the partisan rancor and political division over the issue with "scientific uncertainty". Boykoff and Boykoff (2004, p. 126).study the interaction between the "prestige" press, including the Los Angeles Times, New York Times, Wall Street Journal, and Washington Post, and propose that

prestige press coverage of global warming is not just a collection of news articles; it is a social relationship between people that is mediated by news articles. The parameters of this social relationship are defined, in large part, by the 
many journalistic norms and values that both affect what is deemed news and influence how that news is framed [...]

Boykoff and Boykoff (2004, p. 129) found that during the sampling period of the U.S. prestige press, from 1988-2002,

the majority (52.65\%) of coverage in the US prestige press, balanced accounts prevailed; these accounts gave "roughly equal attention" to the view that humans were contributing to global warming, and the other view that exclusively natural fluctuations could explain the earth's temperature increase. This supports the hypothesis that journalistic balance can often lead to a form of informational bias.

These researchers conclude that

In light of the general agreement in the international scientific community that mandatory and immediate action is needed to combat global warming, US prestige-press coverage has been seriously and systematically deficient (BOYKOFF; BOYKOFF, 2004, p. 134).

Several other studies reveal the important correlation between newspaper coverage in the U.S., public opinion, and partisan-political division on the issues of global warming and climate change. Antilla (2005) also found similar results in a large sample of news coverage on the science of climate change wherein journalistic norms of "balance" led to the dissemination of misinformation from skeptics, often associated with the coal and petroleum industries. She reports,

Not only were there many examples of journalistic balance that led to bias, but some of the news outlets repeatedly used climate skeptics-with known fossil fuel industry ties-as primary definers. Worse yet, in some instances, such articles originated from wire or news service providers (including newspapers that provide such services or are affiliated with news service agencies) - which caused the exponential spread of misinformation (ANTILLA, 2005, p. 350).

Kuha (2009) also explores U.S. media coverage since the 2007 United Nations Climate Change Conference in Bali, Indonesia with a focus on those articles that recognize the anthropogenic sources of global warming. Kuha (2009, p. 9) carefully documents the increasing recognition of climate change science and the anthropogenic sources of global warming by the press since the Bali conference. However, in comparing this trend with the United Kingdom, Kuha (2009, p. 11). 
concludes that U.S. news coverage lags behind in the amount of coverage given to global warming, including causes and effects, while giving greater attention to climate "contrarians" who seek to sow uncertainty and skepticism rather than address the merits of the science and possible policy solutions.

The existing research on U.S. news coverage of global warming and climate change unveils a consistent pattern of reporting, often in the name of journalistic integrity, that gives ample voice to political efforts, often funded by the coal and petroleum industries to erode public confidence in the science of global warming and degrade its policy importance (HOLT, 2006). As Antilla (2005, p. 350). notes, a growing body of literature and research concerned with news coverage and global warming confirms the presence of "media-created obstructions that prevent a more extensive understanding of climate change by the public and policy-makers".

The remarkable variation in U.S. news coverage and the "balanced" reporting that give disproportional importance and credibility to climate change skeptics is also reflected on the editorial pages across the nation. The editors of nationally distributed newspapers, such as the New York Times and the Washington Post, generally favor climate change policy action while the editors of regional and local newspapers express a range of positions with respect to both recognizing climate change science and what to do about it. Just prior to the House of Representatives' vote on the Waxman-Markey climate and energy policy bill, the Washington Post concluded,

After eight years of inaction on global warming, the will to legislate should be celebrated. So should the stated goal: limiting pollution by capping greenhouse gas emissions and putting a price on carbon [...] Even if it passes today, Waxman-Markey is just a first step (WASHINGTON POST WAXMAN-MARKEY..., 2009).

In a similar vein, The New York Times noted that the passage of WaxmanMarkey in the House was a "remarkable achievement," but cautioned that if the U.S. Senate cannot approve similar legislation then the country

would be left with an outdated energy policy and the planet would be stuck with steadily rising emissions [...] The world is waiting for the United States, after years of indifference, to take a strong leadership role. So is the American public (WASHINGTON POST WAXMAN-MARKEY..., 2009). 
While the editors of these prominent newspapers advocate policies to reduce GHG emissions and take the lead in the COP15 negotiations, regional newspapers in predominately Republican strongholds express greater skepticism coupled to a more isolationist international policy position with respect to the COP15 negotiations. The editorial angle held by the Oklahoman, the principal newspaper of the state of Oklahoma and home to ranking Republican Senator James Inhofe of the Environment and Public Works Committee, sharply contrasts with the Washington Post and New York Times, but closely reflects the outlook of the Republican party. In its July 10, 2009 editorial, the Oklahoman concluded, "the science isn't settled, and an emerging Senate majority is right to oppose cap and trade [... ]" and suggested, "there's too much dissent from earlier, dire forecasts to risk wrecking the U.S. economy with carbon emissions legislation."

The Orange County Register of Orange County, California also questions the science of global warming as well as the utility of the Waxman-Markey bill. The paper's June 25, 2009 editorial declared,

The kicker, of course, is that, assuming carbon dioxide emissions caused by human beings cause global warming - still more theory than fact - the highly respected Institute for Energy Research has estimated that the controls in this bill would reduce the global temperature by one-half of 1 degree Fahrenheit. Not very impressive. skeptical of the science, the Register also complained, Not only will this bill do little or nothing to curb global warming - it's all pain and no gain - it has become a Christmas tree for politically connected industries and lobbyists (WASHINGTON POST WAXMAN-MARKEY..., 2009).

Both these editorials are representative of many regional and local newspaper editorial boards that question the science of global warming and sow greater skepticism among the U.S. population. The Orange County Register even goes a step further by discounting current efforts to address the challenge, such as the Waxman-Markey bill, by characterizing the effort as more political patronage than policy solution.

These editorial perspectives sharply deviate from the positions advanced by the Washington Post and New York Times and much of the media coverage in Brazil as documented by ANDI (2009), but reflect a persistent and large plurality of the U.S. population and the political positions held by most members of the 
Republican Party in the U.S. Congress. In the year running up to the COP15 negotiations, both countries saw increased reporting of global warming and climate change issues. In Brazil, increasing coverage further strengthens the national resolve and creates greater opportunities for public discussion of policy alternatives for addressing this global challenge. In the U.S. such "balanced" coverage continues to question the findings of the Intergovernmental Panel on Climate Change (UNITED NATIONS, 2007) and the efficacy of congressional proposals to reduce GHGs. Moreover, increasing coverage in Brazil seems to encourage more and more policymakers, both those supportive of the Lula administration and those opposed to it, to propose increasingly rigorous policy alternatives to limit GHGs and deforestation. In the U.S., the debate over global warming in the pages of the press further fragments public opinion and undermines effective policymaking to address climate change both at home and through international negotiations.

\section{Policymakers}

These major differences between Brazil and the U.S. are crystallized through a concise review of the positions and perspectives offered by these two countries' leading policymakers in the executive and legislative branches. Brazilian government leaders largely agree on the importance of climate change as a framework for developing public policy while their U.S. colleagues are engulfed in the partisan enmity between Democrats and Republicans whereby climate change is a strong correlate of party identification and voting behavior rather than a common cause shared across political ideologies and parties. This is not to suggest that Brazilian policymakers agree on the best set of policy prescriptions or even negotiating strategies for the COP15. Rather, most Brazilian political parties and policymakers now compete among themselves to champion the issues of climate change and sustainable development.

President Lula's recent remarks demonstrate the race to herald the environment as a national cause. At a speech given at the Ministry of the Environment in August of 2008, President Lula reminded his audience that, 
Brazil will certainly carry out all of its responsibilities to preserve the Amazon and combat global warming because our nation wants to not only assume our responsibilities, but also to exercise sovereignty over all of our Amazon territory, over all of our national decisions [...] To destroy it would be an instrument used against our nation and our products (SILVA, L., 2008).

President Lula's administration has worked to balance its drive for national economic development with efforts to mitigate carbon dioxide emissions from fossil fuel use and deforestation. The administration's leading policymaker for climate change is José Miguez, General Coordinator of Global Climate Change for the Ministry of Science and Technology (MCT) and Executive Director of the Inter-ministerial Commission on Global Climate Change. Since the early 1990s, Miguez has coordinated the MCT's research on global warming and climate change and most recently played a lead role in formulating Brazil's National Climate Change Plan. Miguez reports that,

Brazil is willing to contribute to the global effort to address the climate change challenge in proportion to its historic responsibility. Hence, we have a series of policies and programs that are effectively reducing greenhouse gas emissions and making the Brazilian energy matrix cleaner, with lower levels of GHG emissions by unit of energy produced and consumed (MIGUEZ, 2009).

Brazil's Foreign Minister, Celso Amorim, also committed the country to reducing GHG emissions, but singled out the U.S. as a major detractor in the global effort to address global warming,

Those historically responsible for greenhouse gas concentrations in the atmosphere must stop preaching and set the example. Annex I countries must have new and more ambitious legally-binding emission reduction targets. It is extremely worrying that some developed countries do not appear to be heading towards meeting their targets under the Kyoto Protocol even as the biggest emitter [the U.S.] still refuses to join the Protocol. Nor have these countries complied with their commitments on financial assistance and technology transfer under the Convention... Brazil, for its part, is ready to enhance its policies and programs to reduce emissions in a way that is measurable, verifiable and open to universal periodic review. We invite other developing nations, in a position to do so, to follow the same path (AMORIM, 2007). 
Amorim's remarks are also echoed by Brazilian congressional leaders across the party spectrum. Senator Marina Silva of Acre, former Minister of the Environment under the Lula administration and one of the founders of President Lula's Workers Party, asserted the government's position with respect to global warming and the significance of deforestation,

Humanity should make every effort to prevent this, not only in the Amazon forest but in all of the planet's forests that are threatened [...] A shoving match doesn't solve anything. Everybody has to do their part. The rich are pointing at the poor (countries) and the poor, at the rich, when we are all running the risk of seeing this catastrophe happen (SILVA, M., 2007).

Two years later, Senator Marina Silva announced her departure from the Workers Party in anticipation of becoming the presidential nominee for the Green Party (PV) to place the environment and sustainable development as the cornerstone of her campaign and at the center-stage of the nation's presidential politics in advance of the 2010 election.

In the Brazilian Congress legislative opposition to the Lula administration advocates stronger national efforts to reduce GHG emissions. Federal Deputy Antonio Carlos Mendes Thame is a congressional leader on climate change policy and leading spokesperson for the Brazilian Social Democrat Party (PSDB) which heads up the congressional opposition to the Lula administration. He also calls on developed countries to step up their efforts to reduce GHG emissions, but calls for more rigorous measures to combat deforestation in Brazil along with acceptance of mandatory GHG emissions reductions under the post-Kyoto Protocol agreement. He argues,

It is essential that we solve our biggest environmental and political problem that we confront inside our national borders, deforestation in the Amazon. Our environmental Achilles heel is the burning of the forest and illegal deforestation (THAME, 2008).

Deputy Thame also weighs in on the Lula administration's objections to mandatory emission reductions under a post-Kyoto Protocol agreement, arguing,

By refusing to adopt mandatory emission reductions, Brazil, along with China and India, contribute to reinforcing the Bush administration's position that justifies inaction by 
opposing voluntary reductions for developing countries and mandatory financial contributions paid by Annex I countries (THAME, 2008, p.1).

In sharp contrast to the U.S., the Brazilian executive and legislature are moving forward with stronger efforts to address global warming, propelled in some measure by electoral politics and the growing importance of environmental policy to voters. In the U.S., domestic policies and international positions are very much circumscribed by the political division and partisan wrangling over the science of global warming and its policy implications. Thus, electoral politics undermines efforts to forge a national consensus and pass significant energy and climate change legislation in advance of Copenhagen.

President Obama offered up his own analysis of the politics of climate change legislation in the U.S. Congress,

I think that the Waxman-Markey bill represents a great start. And I suspect that the Senate is going to come in - that there's going to be a strong overlap, but not perfect overlap; the final legislation that emerges is probably not going to satisfy the Europeans or Greenpeace. (INTERVIEW with..., 2009).

Todd Stern, the U.S. State Department's Special Envoy for Climate Change, reasoned along with William Antholis before President Obama's election,

With a nation ready to be led on this issue and an international community waiting for the United States to finally stand up, the next president has a pivotal opportunity to shift course and take bold, broad action. His or her first mission must be to implement a serious, mandatory climate program at home, not only because the United States is a dominant producer of heat-trapping greenhouse gases, but also because it will have no international credibility unless and until it acts decisively at home (STERN, 2007, p. 175176).

The Obama administration has assembled a prominent team of climate change policy makers, including Todd Stern to lead the U.S. delegation at Copenhagen, as well as the placement of Nobel Prize winning Steven Chu as Secretary of Energy, former Administrator of the Environmental Protection Agency, Carol Browner, as President Obama's Assistant to the President for Energy and Climate Change, and John Holdren as the President's chief advisor on science 
and technology and Director of the White House Office of Science and Technology Policy. Yet, the real question, as Stern and Antholis pose, can the U.S. Congress pass mandatory GHG emission reduction legislation? Although President Obama has assembled "a team with unmatched knowledge and commitment to solve the climate problem (Romm Jan. 26, 2009)," it is not clear that such a distinguished team can overcome divergent perspectives and partisan rancor to pass significant legislation before the COP15 in December of 2009.

Democratic Senator Barbara Boxer, Chair of the U.S. Senate's Environment and Public Works Committee and sponsor of numerous climate change bills, reflects the Obama administration's partial understanding of the global warming problem as a doubled edged technology and leadership challenge. She concludes, "the nation that aggressively addresses the issue of climate change will be the nation that will thrive, the nation that will lead, the nation that will prosper" (BOXER, 2009, p. 1).

Her outlook also parallels that of Senator John Kerry who chairs the Senate Foreign Relations Committee and is likely to jointly propose climate change legislation in the fall of 2009 with Senator Boxer. He adds,

We don't want [to be] divisive, we don't want anything partisan out of this. It's not a partisan issue. This is an issue that ought to be based on science, on facts, on economics, and on good environmental policy - good economic policy, may I add significantly. I mean, this bill is really a bill for the transformation of the American economy. This bill is about jobs - clean energy jobs that stay here in America, that pay people decent salaries. (KERRY, 2009).

However, Senators Boxer and Kerry's attempts to "sell" climate change legislation in the U.S. Senate come into conflict with the Republican Party's rebuttal of global warming science and steadfast opposition to mandatory GHG emission reductions. Republican Senator James Inhofe of Oklahoma, the leading opposition voice to climate change policy in the Senate, once commented that global warming is "hoax" and defended his position on the Senate floor on May 12,2009 by reporting,

You should never underestimate the intelligence of the American people. Sadly, that is exactly what the promoters of man-made climate fears have been consistently doing, 
and the American people have consistently rejected climate alarm. Despite world-wide media frenzy, Americans remain as skeptical of global warming fears as they were in 1989 (INHOFE, 2009).

Michael Steele, Chair of the Republican Party, echoes Senator Inhofe's perspective on validity of global warming science. On a popular Republican radio program, Steele (apud STEIN, 2009) explained,

We are cooling. We are not warming. The warming you see out there, the supposed warming, and I am using my finger quotation marks here, is part of the cooling process. Greenland, which is now covered in ice, it was once called Greenland for a reason, right?

Both Inhofe and Steele provide a popular voice for a sizeable plurality of U.S. citizens who doubt global warming science and are resistant to the types of climate change policies advocated by the Obama administration and advanced by the Waxman Markey bill. The transparent division in understanding climate change among U.S. legislators and party leaders stands in sharp contrast to Brazil where legislators trust the science and are increasingly supportive of more aggressive national and international efforts to address global warming, often competing among themselves to champion this cause. In Brazil, partisan contestation is fueling greater political attention to the environment, deforestation, and global warming. In the U.S., such contestation only serves to deepen the cognitive divide between U.S. citizens on these vital issues of global importance and international leadership.

\section{Thinking Copenhagen}

Brazil's cognitive foundation provides a sturdy, popular platform for those advocating more aggressive national policies to mitigate GHG emissions and widen this nation's win-set of strategic positions at the COP15 negotiations. The Brazilian government's insistence that developed countries, especially the U.S., do more to mitigate GHG emissions, is echoed by nearly every congressperson and executive branch policymaker. However, the country's policy debate of climate change and Cophenhagen has yet to fully incorporate the impact of the new oil reserve discoveries that could lead to Brazil's exportation of crude oil and petroleum 
products in the coming years. These new discoveries could lead to greater international pressure on Brazil to accept GHG emissions targeting. Moreover, much of the political contestation and policy debate surrounding the COP15 deliberations revolves around the question of whether Brazil should reverse its historic position and begin to support mandatory emission reductions for the large, developing country emitters including itself, China and India (VIOLA, 2009). Increasingly, Brazilian policymakers and leading politicians hint at this possibility, further widening Brazil's win-set and opening up many negotiating opportunities to play a deal making role at Copenhagen. If anything, Brazil's political cohesion on matters of international climate change coupled with its recent oil reserve discoveries serve to undermine its historical opposition to mandatory emission reductions for developing countries. Yet, the developed Annex I countries interested in expanding mandatory emission reductions will most certainly highlight the country's broad support for taking on more responsibilities, albeit differentiated by this nation's unique place in the global warming equation.

The opposite is true for the U.S. This country's cognitive foundation is discordant, its public opinion is divided, and leading Republican Party lawmakers openly doubt global warming science and often argue that climate change policy costs too much. The effects of such cognitive incongruity may indeed "tie the hands" of the Obama administration's negotiators at the COP15, shrink this pivotal nation's win-set of strategic positions, and possibly compel such countries as Brazil to make major concessions for the sake of striking an agreement that can be ratified by the U.S Senate. If the Kyoto Protocol negotiations in 1997 are any lesson, President Obama's elite team of climate change policymakers may extend U.S. negotiating positions beyond political possibilities and cognitive frame for policymaking. Indeed, such an ambitious team of policymakers and negotiators may subject the U.S. President to an involuntary defection from an agreement forged in Copenhagen and rejected by enough U.S. senators to spoil any hopes of ratification.

Where are the possibilities for further bilateral cooperation on the road to Copenhagen? While Brazil and the U.S. do not share sufficient cognitive understanding to drive negotiations toward an historic breakthrough at Copenhagen, their strategic positions may overlap on particular issues that could frame a post-Kyoto Protocol regime. Should Brazil commit itself to emission reduction 
targets, and convince China and India to adopt such a position, it would increase the international pressure on the U.S. administration and Senate to deepen national efforts and legislative initiatives to lessen GHG emissions. However, developing country targets and reductions could only be met through accelerated transfers of technology and greater financial resources, possibly engineered through a rapid expansion of the CDM. The current ethanol tariff debacle between Brazil and the U.S. coupled to the less than impressive results of the bilateral biofuel accord do not bode well for U.S. support of expanding technology transfer or increases in financial assistance. Indeed, under the Waxman-Markey bill, should the U.S. move toward a cap and trade system of carbon emission commercialization, most carbon intensive industries would receive handsome offsets for years to come, further limiting the possibilities of rapidly expanding such financial mechanisms as the CDM.

Brazil's broad win-set, partially defined through its strong consensus favoring international climate change action, provides the Lula administration with the flexibility of forging an historic agreement at Copenhagen. Yet, given the limits to U.S. win-set at Copenhagen, Brazilian negotiators will need to carefully focus and craft the country's negotiating positions to parallel the political possibilities of the U.S. Senate and budge the U.S. toward those points of overlap that maximize the dissemination of low carbon, low cost technologies that provide Brazil and the rest of the developing world an opportunity to bundle sustainable economic development with the multilateral effort to address global warming.

\section{Pensando Copenhague: a dimensão cognitiva do "fazer" político da mudança de clima no Brasil e nos Estados Unidos}

Este artigo explora a dimensão cognitiva do "fazer" político da mudança de clima no Brasil e nos Estados Unidos, já que ambos se preparam para a Conferência Quadro de Mudanças Climáticas das Nações Unidas ou COP15, em Copenhagen. A análise política comparativa é baseada no modelo de Putnam (1988), utilizada por Bazerman (2009), mas adaptada para explorar expressões cognitivas do "fazer" político por meio de investigação da opinião pública, cobertura jornalística e classe política. A análise revela diferenças chave nos modos que cidadãos, 
jornalistas e políticos brasileiros e norte-americanos entendem o aquecimento global e a mudança de clima e pensam políticas alternativas para este desafio global, por meio da política nacional e das negociações internacionais. A dimensão cognitiva do Brasil concede a seus negociadores uma ampla margem de posições estratégicas, permitindo a este país jogar um papel de negociador. A administração norte-americana chega em Copenhagen com uma estreita capacidade de ganho, limitada por discordâncias e por expressões cognitivas divididas que envolvem o fazer político. Estas diferenças limitam a cooperação bilateral e complicam as negociações da COP15.

Palavras-chave: Mudança climática. Aquecimento global. Emissão de gases de efeito estufa. Protocolo de Kyoto. Cobertura da mídia e jornais. Criação de procedimentos. Opinião pública.

\section{Bibliography}

ANDI. Mudanças climáticas na imprensa brasileira. [S.l.]: ANDI, 2009.

AÍMOLA, L. A. L.; DIAS, P. L. Silva. A incerteza científica e a opinião pública na balança das negociações sobre mudança de clima. Revista de Gestão Integrada em Saúde do Trabalho e Meio Ambiente, [S.1.], v. 2, n. 5, p. 1-8, Dec. 2007.

AMORIM, Celso. Speech by the Foreign Minister of Brazil, ambassador Celso Amorim, at the High Level Segment of the 13th Conference of the Parties to the United Nations Framework Convention on Climate Change and the 3rd Conference of the Parties serving as Meeting of the Parties to the Kyoto Protocol. Bali, Indonesia. Dec. 12, 2007.

ANTILLA, Lissa. Climate of skepticism: US newspaper coverage of the science of climate change. Global Environmental Change. [S.1.], v. 15, p. 338-352, 2005.

BAZERMAN, Max. H. Barriers to acting in time on energy and strategies for overcoming them. In: GALLAGHER, Kelly Sims. Acting in time on energy policy. Washington, D.C.: Brookings Institution, 2009.

BOXER, Barbara. Nations aggressive on climate change will be the ones that lead, and prosper. The Hill, Washington D. C., 21 July 22, 2009. Available at: <http:// thehill.com/special-reports/energy-july-2009/51305-nations-aggressive-on-climatechange-will-be-the-ones-that-lead-and-prosper>. Access on: Sept. 26, 2009. 
BOYKOFF, Maxwell T.; BOYKOFF, Jules M. Balance as bias: global warming and the US prestige press. Global Environmental Change, [S.1.], n. 14, p. 125-136, 2004.

BRYNER, Gary. Failure and opportunity: environmental groups in US climate change policy. Environmental Politics, [S.1.], n. 2, p. 319-336, April 2008.

CAVALCANTI, Carlos A., BONOMO, Diego Z. Estados Unidos e Brasil: de Copenhague a Genebra. FATOR Ambiental, São Paulo, Apr. 27, 2009. Available at: <http://www.fatorambiental.com.br/portal/index.php/2009/ 04/28/mudancasclimaticas-16/>. Access on: Sept. 25, 2009.

CLIMATE in the Senate. New York Times, Ney York, July 1, 2009.

DIRIKX, Astrid; GELDERS, Dave. Newspaper communication on global warming: different approaches in the US and the EU? In: CARVALHO, Anabela (Ed.). Communicating climate change: discourses, mediations and perceptions. Braga: Universidade do Minho, 2008.

GONÇALVES, Janayde de Castro. Agendamento e frames da questão climatica nos impressos brasileiros. In: ENCONTRO NACIONAL DE PESQUISADORES EM JORNALISMO, 6., 2008, São Paulo. Anais... São Paulo: UMESP, 2008.

HOLT, Norah. Climate change skeptics. ISEMA: Perspectives on Innovation, Science and Environment, [S.1.], v. 1, p. 1-17, 2006.

HOUSER, Trevor; SHASHANK, Mohan; HEILMAYR, Robert. A Green Global Recovery? Assessing US Economic Stimulus and the Prospects for International Coordination. World Resources Institute, Washington D. C., Feb. 2009. Available at: <http://www.wri.org/publication/green-global-recovery>. Access on: Sept. 26, 2009.

INHOFE, James. Gallup poll: record-high $41 \%$ of americans now say global warming is exaggerated. US Senator James Inhofe, Oklahoma, Mar. 12, 2009. Available at: <http://inhofe.senate.gov/public/index.cfm?FuseAction $=$ PressRoom.Speeches \&ContentRecord_id=fc755d57-802a-23ad-4356-bbde b75697f4\&Region_id=\&Issue_id >. Access on: Sept. 25, 2009.

INTER-AMERICAN DIALOGUE. A second chance: U.S. policy in the Americas. Washington, D.C. March, 2009. Available at: <http://www.thedialogue.org/ PublicationFiles/A\%20Second\%20Chance,\%20 FINAL\%20to\%20post.pdf $>$. Access on: Sept. 26, 2009. 
INTERVIEW with president Obama on climate bill. New York Times, Ney York, June 28, 2009.

ISBELL, Paul. Energy and geopolitics in Latin America. Elcano Real Instituto, Oct. 3, 2008 .

KERRY, John. Sen. Kerry on climate bill: 'we're going to get it done'. Environmental 360. New Haven, July 27, 2009. Available at: <http://e360.yale.edu/content/feature. msp?id=2174>. Access on: Sept. 25, 2009.

KUHA, Mai. Uncertainty about causes and effects of global warming in U.S. news coverage before and after Bali. Language \& Ecology, [S.1.], v. 2, n. 4, 2009.

LANGEVIN, Mark S. Renewable cooperation? Reflections on United States-Brazil cooperation on biofuels. American Diplomacy. Nov. 25, 2008. Available at: <http:// www.unc.edu/depts/diplomat/item/2008/1012/comm/ langevin_biofeul.html. Access on: Sept. 26, 2009.

LANGEVIN, Mark S. Será que as laranjas e a cana-de-açúcar da Flórida azedam o Livre Comércio? Uma análise de ratificação de nível II da política comercial dos Estados Unidos com o Brasil. Contexto Internacional, Rio de Janeiro, v. 28, n. 1, p. 167-221, Jan./Jun. 2006.

LANGEVIN, Mark S.; BAEZA, Gonzalo. The convergence we need? President Obama and United States policy in Latin America and the Caribbean. American Diplomacy, [S.1.], Mar. 31, 2009 Available at: <http://www.unc.edu/depts/diplomat/ item/2009/0103/comm/baezalangevin_convergence.html $>$. Access on: Sept. 25, 2009.

LIEBERTHAL, Kenneth; SANDALOW, David. Overcoming obstacles to United States-China cooperation on climate change. Brookings Institution, [S.1.], Jan. 15, 2009. Available at: <http://www.brookings.edu/ reports/2009/01_climate_change_ lieberthal_sandalow.aspx>. Access on: Sept. 26, 2009.

MIGUEZ, José. Entrevista exclusiva: José Miguez. FATOR ambiental, São Paulo, Mar. 6, 2009. Available at: <http://www.fatorambiental.com.br/ imprensa/ entrevista-jose-miguez.php>. Access on: Sept. 26, 2009.

OBERTHÜR, Sebastian; OTT, Hermann. The Kyoto Protocol: international climate policy for the $21^{\text {st }}$ century. New York: Springer. 1999. 
Orange County Register. Climate change bill all pain, and no gain. Oc register, Orange County, June 25, 2009. Availabe at: <http://www.ocregister.com/articles/ energy-bill-cap-2473738-carbon-trade>. Access on: Sept. 25, 2009.

PALFREMAN, J. A tale of two fears: exploring media depictions of nuclear power and global warming. Review of Policy Research, [S.1.], v. 23, n. 1, p. 23-43, 2006.

PEW RESEARCH CENTER. A deeper partisan divide over global warming. In: . The pew global attitudes project. Washington D.C., 2008.

PEW RESEARCH CENTER. Common challenge, collaborative response: a roadmap for United States -China Cooperation on energy and climate change. In: . The Pew Center on Global Climate Change and the Asia Society. Washington D.C., Jan. 2009a.

PEW RESEARCH CENTER. Confidence in Obama lifts U.S. image around the world. In: . The pew global attitudes project. Washington D.C., Jul. $2009 \mathrm{~b}$.

PEW RESEARCH CENTER. Global unease with major world powers. In: The pew global attitudes project. Washington D.C., 2007.

PEW RESEARCH CENTER. Policy Update. In: . The pew global attitudes project. Washington D.C., Mar. 2009c.

PEW RESEARCH CENTER. What the world thinks in 2002. In: The pew global attitudes project. Washington D.C., Dec. 2002.

PUTNAM, Robert D. Diplomacy and domestic politics: the logic of two-level games. International Organization, [S.1.], v. 42, n. 3, p. 427-460, 1988.

ROMM, Joseph. Real Science comes to Washington. Salon.com, [S.I.], Jan. 26, 2009.

SAAD, Lydia. Increased number think global warming is "exaggerated". Gallup, Washington D. C., Mar. 11, 2009. Avalible at: <http://www.gallup.com/poll/116590/ increased-number-think-global warming exaggerated.aspx>. Access on: Sept. 26, 2009.

SEELKE, Clare Ribando; MEYER, Peter. Brazil - U.S. relations. Congressional Research Service, [S.1.], Jan. 21, 2009.

SENNES, Ricardo Ubiraci; NARCISO, Thais. Brazil as an International Energy Player. In: . Brazil as an Economic Superpower? Understanding Brazil's changing role in the global economy. Washington, D.C.: Brookings Institution, 2009. 
SILVA, Luiz Inácio Lula da. Discurso do presidente da República, Luiz Inácio Lula da Silva, durante cerimônia de assinatura de atos do Ministério do Meio Ambiente Rio de Janeiro, Ago. 1, 2008.

SILVA, Marina. Global warming demands global effort, Brazil. Reuters, [S.1.], Feb. 4, 2007.

STEIN, Sam. Steele's tour-de-force: compares Obama to Nixon, declares "ultimate political armageddon," backs challenges against republicans. The Huffington Post, Chicago, Apr. 16, 2009. Available at: <http://www.huffingtonpost.com/2009/03/16/ steeles-tour-de-force-com_n_175317.html>. Access on Sept. 25, 2009.

STERN, Nicholas. The economics of climate change: the stern review. Cambridge: Cambridge University Press, 2007.

STERN, Todd; ANTHOLIS, William. A changing climate: the road ahead for the United States. The Washington Quarterly, Washington D.C., v. 31, n. 1, p. 175-188, Winter 2007-2008.

THAME, Antonio Carlos Mendes. Câmara dos Deputados - DETAQ. Brasília, Dec. 22, 2008. Available at: <http://www.camara.gov.br/internet/ sitaqweb/TextoHTML. asp ? etapa $=5 \&$ nuSessao $=094.3 .53 .0 \% 20 \% 20 \% 20 \% 20 \% 20 \&$ nuQuarto $=64 \& \mathrm{n}$ uOrador $=1 \&$ nuInsercao $=0 \&$ dtHorarioQuarto $=16: 06 \& \operatorname{sgFaseSessao}=\mathrm{GE} \% 20$ $\% 20 \% 20 \% 20 \% 20 \% 20 \% 20 \% 20 \& D a t a=06 / 05 / 2009 \&$ txApelido=ANTONIO $\% 20$ CARLOS\%20MENDES\%20THAME,\%20PSDB-SP\&txFaseSessao=Grande $\% 20$ Expediente\%20\%20\%20\%20\%20\%20\%20\%20\%20\%20\%20\%20\%20\&txTipoSessao=Ordin $\%$ E1ria $\% 20-20 \mathrm{CD} \% 20 \% \quad 20 \% 20 \% 20 \% 20 \% 20 \% 20 \% 20 \% 20 \% 20 \% 20$ $\% 20 \% 20 \% 20 \% 20 \% 20 \& d t H o r a Q u a r t o=16: 06 \&$ txEtapa=>.Access on: Sept. 26, 2009.

UNITED NATIONS. Climate change 2007: a synthesis report. Washington D. C., 2007.

VIOLA, Eduardo. O Brasil na arena internacional da mitigação da mudança climática. Rio de Janeiro: CINDES, 2009.

VIOLA, Eduardo; LEIS, Hector. Brazil and Global Governance: the case of climate change. Florianópolis: Universidade Federal de Santa Catarina, Mar. 2001. Working Paper. 
WARMING debate simmers as Obama poses in Europe. The Oklahoman, Oklahoma, July 10, 2009. Available at: <http://newsok.com/warming-debatesimmers-as-obama-poses-in-europe/article/3384140>. Access on: Sept. 25, 2009.

WAXMAN-MARKEY, action on climate change is overdue: but is this the best we can hope for? Washington Post, Washington D. C., June 26, 2009. Available at: <http://www.washingtonpost.com/wpdyn/content/article/2009/ 06/25/ AR2009062503469.htmland>. Access on: September 25, 2009.

WEINTRAUB, Sidney; HESTER, Annette; PRADO, Veronica R. (Ed.). Energy cooperation in the western Hemisphere: benefits and impediments. Washington, D.C.: CSIS, 2007. 